\title{
Adsorption of Cr(VI) by Natural Clinoptilolite Zeolite from Aqueous Solutions: Isotherms and Kinetics
}

\author{
Sahand Jorfi ${ }^{*}$, Mohammad Javad Ahmadi², Sudabeh Pourfadakari ${ }^{2}$, Nematollah Jaafarzadeh ${ }^{1}$, \\ Reza Darvishi Cheshmeh Soltani ${ }^{3}$, Hamideh Akbari ${ }^{4}$ \\ ${ }^{1}$ Ahvaz Jundishapur University of Medical Sciences, Environmental Technologies Research Center, Ahvaz, Iran \\ ${ }^{2}$ Ahvaz Jundishapur University of Medical Sciences, Department of Environmental Health Engineering, School of Health, \\ Ahvaz, Iran \\ ${ }^{3}$ Arak University of medical Sciences, Department of Environmental Health Engineering, School of Health, Arak, Iran. \\ ${ }^{4}$ Zahedan University of Medical Sciences, Department of Environmental Health Engineering, School of Health, Zahedan, \\ Iran \\ "Corresponding author: e-mail: sahand369@yahoo.com,Taknavaz1360@yahoo.com
}

\begin{abstract}
The main aim of this study was to evaluate the efficiency of natural zeolite for $\mathrm{Cr}(\mathrm{VI})$ removal from aqueous solutions. Following simple modification of adsorbent, the effect of operational parameters including $\mathrm{pH}(2-10)$, adsorbent dosage $(2-20 \mathrm{~g} / \mathrm{L})$, contact time $(5-150 \mathrm{~min})$ and $\mathrm{Cr}(\mathrm{VI})$ concentration $(10-50 \mathrm{mg} / \mathrm{L})$ were studied according to one-factor-at-a-time procedure. The maximum $\mathrm{Cr}(\mathrm{VI})$ removal of $99.53 \%$ was obtained at initial $\mathrm{pH}$ of 2, contact time of $30 \mathrm{~min}$, adsorbent dosage of $8 \mathrm{~g} / \mathrm{L}$ and initial chromium concentration of $10 \mathrm{mg} / \mathrm{L}$. The Freundlich isotherm was best fitted with experimental data $(\mathrm{R} 2=0.951)$. Also, type 1 pseudo second order kinetic model showed the most correlation $(\mathrm{R} 2=1)$ with the experimental data. According to obtained results, it can be concluded that the application of clay-like adsorbents such as natural clinoptilolite zeolite can be considered as an efficient alternative for final treatment of effluents containing $\mathrm{Cr}(\mathrm{VI})$.
\end{abstract}

Keywords: Adsorption, Clinoptilolite Zeolite, Cr(VI), Isotherm, Reaction Kinetics.

\section{INTRODUCTION}

The water contamination to heavy metals has been considered as an environmental concern due to their toxicity, health effects, long persistence and bioaccumulation in the food chain. Heavy metals even at low concentrations are toxic to humans, flora and fauna ${ }^{1}$. Chromium is one of the most hazardous toxic metals and is released through effluents of photography, leather, ceramics and glass industries, pigments, dyes, fungicides and $\mathrm{Cr}(\mathrm{VI})$ alloy production. The uptake of $\mathrm{Cr}(\mathrm{VI})$ at concentration more than $0.1 \mathrm{mg} / \mathrm{L}$ by humans can cause poisoning, vomiting, bleeding, nose irritation, skin ulcers, lung cancer and respiratory diseases such as asthma ${ }^{2}$.

$\mathrm{Cr}(\mathrm{VI})$ with high mobility can rapidly penetrate into surface and ground water and cause to hazardous effects on any living life. In addition, $\mathrm{Cr}(\mathrm{VI})$ can easily diffuse and cross in cell membranes ${ }^{3}$.Therefore, International Agency for Research on Cancer (IARC) and the United States Environmental Protection Agency (EPA), classify Cr(VI) as a carcinogenic substance for humans. The maximum allowable concentration (MAC) of $\mathrm{Cr}(\mathrm{VI})$ in soil and drinking water are 0.1 and $0.05 \mathrm{mg} / \mathrm{L}$, respectively. Different removal methods including chemical precipitation, ion exchange, electrochemical precipitation ${ }^{4}$, filtration, evaporation and membrane technologies are applied for treating industrial effluents $\mathrm{Cr}(\mathrm{VI})$-containing effluents ${ }^{5}$. These processes may be inefficient or not cost effective due to initial high $\mathrm{Cr}(\mathrm{VI})$ concentrations. Another problem with conventional treatment technologies is production of considerable amounts of toxic sludge which makes the overall treatment and disposal incompatible with the environmental friendly processes ${ }^{6}$. Considering the above-mentioned statements ${ }^{7}$, the removal of toxic heavy metals in an environmentally friendly and cost-effective manner is very important ${ }^{2}$. The use of adsorbents such as activated carbon, inorganic materials such as zeolite and clay, biological adsorbents and industrial wastes for removal of metal ions has been increasingly studied ${ }^{8,9}$. In recent years, researchers have paid considerable attention on the use of natural wastes as an effective alternative for adsorption of heavy metals ${ }^{2}$. Among the various removal technologies of heavy metals from water and wastewater, sorption by zeolites has been deeply studied due to their efficiency, economical aspects and ease of access. Special characteristics of natural zeolites such as clinoptilolite include ion exchange capability, molecular sieve, abundance, low cost, capability to be used as a support for photocatalysts and compatibility with the environment ${ }^{10,11}$. The internal crystalline and complex structure has led to high specific surface area of these natural compounds up to $300 \mathrm{~m}^{2} / \mathrm{g}^{12-14}$. Due to presence of a net permanent negative charge of zeolites they count as good cation exchangers ${ }^{15-17}$. Owing ion exchange and adsorption characteristics, these structures are able to remove majority of the water soluble compounds. Chromium form oxyanions in aqueous solution, consequently the resulting negative ions reduce the cationic exchange capacity and adsorption ability increases ${ }^{18}$.

According to absorptive characteristics of natural zeolites, the main purpose of the present study was to determine the removal efficiency of $\mathrm{Cr}(\mathrm{VI})$ from aqueous solutions using natural Clinoptilolite and describing the isotherm model.

\section{EXPERIMENTAL}

\section{Material}

Removal experiments in this study were carried out using synthetic wastewater prepared by Merck chemicals. The Clinoptilolite zeolite was purchased from Afrazand Mining Corporation. The $\mathrm{Cr}(\mathrm{VI})$ stock solution was produced using potassium dichromate $\left(\mathrm{K}_{2} \mathrm{Cr}_{2} \mathrm{O}_{7}\right)$.The range 
of chromium concentrations were selected according to usual $\mathrm{Cr}(\mathrm{VI})$ concentrations in industrial wastewater and were prepared on a daily basis. The $\mathrm{pH}$ was adjusted by $0.1 \mathrm{M} \mathrm{HCl}$ and $0.1 \mathrm{M} \mathrm{NaOH}$ and measured by a digital pH meter (Model: Cyberscaneutech-instruments 5500).

\section{Adsorbent preparation}

Following zeolite preparation, the samples were milled and screened through ASTM standard sieves with the mesh No $40^{19}$. Then the zeolites were washed with distilled water to remove fine particulate matter and mineral salts. In order to remove any water soluble and magnetic impurities, the obtained powder was heated at $70^{\circ} \mathrm{C}$ in distilled water for $8 \mathrm{~h}$ on a magnetic stirrer ${ }^{20}$.

This process was repeated three times. To remove moisture from the internal cavities of zeolite and creating space for sorption, the samples were heated for 24 hours at temperatures above $100^{\circ} \mathrm{C}^{\mathbf{1 3}}$.

\section{Experimental procedure}

Experiments were done in 100-mL Erlenmeyer flasks as batch flow mode experimental reactors. The reactors were stirred using a shaker at $150 \mathrm{rpm}$ and at room temperature $\left(24-26^{\circ} \mathrm{C}\right)$. The operational parameters influencing $\mathrm{Cr}(\mathrm{VI})$ removal by zeolite including contact time, initial $\mathrm{Cr}(\mathrm{VI})$ concentration and adsorbent dosage were studied according to one factor at the time experimental design ${ }^{\mathbf{1 9}}$. Results were analyzed according to removal efficiency using Eq. (1) as bellow:

Removal $(\%)=\left(C_{0}-C_{t}\right) / C_{0} \times 100$

where $\mathrm{C}_{0}$ and $\mathrm{C}_{\mathrm{t}}$ are initial and final $\mathrm{Cr}(\mathrm{VI})$ concentration. In addition, the adsorption equilibrium in aqueous solution was determined using Eq. (2):

$q=\left(C_{0}-C_{e}\right) \mathrm{V} / \mathrm{m}$

where, $\mathrm{q}$ is the amount of $\mathrm{Cr}(\mathrm{VI})$ adsorbed at equilibrium condition $(\mathrm{mg} / \mathrm{g}), \mathrm{C}_{0}$ is the initial $\mathrm{Cr}(\mathrm{VI})$ concentration $(\mathrm{mg} / \mathrm{L}), \mathrm{C}_{\mathrm{e}}$ is the equilibrium concentration of $\mathrm{Cr}(\mathrm{VI})$ $(\mathrm{mg} / \mathrm{L}), \mathrm{m}$ is the adsorbent mass $(\mathrm{g})$ and $\mathrm{V}$ is the volume of solution $(\mathrm{L})^{\mathbf{2 1}}$. The study procedures are shown in Table 1. Also, reusability of clinoptilolite natural zeolite was studied through four adsorption-desorption cycles. For desorption study, used clinoptilolite zeolite was submerged in the $0.1 \mathrm{M} \mathrm{H}_{2} \mathrm{SO}_{4}$ and placed on a shaker at $150 \mathrm{rpm}$ for $120 \mathrm{~min}$ at $25 \pm 2^{\circ} \mathrm{C}$. The $\mathrm{Cr}(\mathrm{VI})$ initial concentration of $50 \mathrm{mg} / \mathrm{L}$ was used in these experiments.

\section{Adsorption isotherms}

The adsorption isotherm indicates the amount of substance adsorbed by unit mass of adsorbent at a constant temperature in equilibrium conditions. The Langmuir, Freundlich, Temkin and Dubinin- Radushkevich (D-R) isotherms were studied for the experimental data. The study of isotherm models were carried out in $\mathrm{pH}$ of the solution, adsorbent dosage, agitation speed and contact time of $2,8 \mathrm{~g} / \mathrm{L}, 150 \mathrm{rpm}$ and $30 \mathrm{~min}$, respectively.

\section{Analytical methods}

The $\mathrm{Cr}$ (VI) concentration was determined by flame atomic absorption spectroscopy (FAAS) (Model AAS vario 6). Samples were prepared according to standard methods for examination of water and wastewater ${ }^{22}$. The zeolite chemical composition was determined by X-ray diffraction (XRD) and X-ray Fluorescence (XRF). Surface morphology of the samples was characterized using scanning electron microscopy (SEM) via a XL30, Philips microscope. In addition, the specific surface area of as-prepared adsorbent was determined by BET analysis (MODEL: Nanosord, made in Iran).

\section{RESULTS AND DISCUSSION}

\section{Characterization of natural clinoptilolite zeolite}

According to XRD analysis, silica, aluminum, iron, potassium, magnesium and calcium were present in zeolite samples (Fig. 1). The main dominant peaks of natural clinoptilolite were placed at $2 \theta$ of $10.17^{\circ}, 12.05^{\circ}$, $13.43^{\circ}, 17.66^{\circ}, 22.70^{\circ}, 28.45^{\circ}, 30.23^{\circ}$ and $56.95^{\circ}$ illustrating the presence of minerals like $\mathrm{Al}, \mathrm{Si}, \mathrm{Na}, \mathrm{K}$ which is in good agreement with the standard JCPDS card no: $(25-1349)^{\mathbf{2 3}}$. There are some similarities and also differences with other studied clinoptilolites in literature, for example in a sample studied by Derikvandi, and Nezamzadeh-Ejhieh (2017) for a zeolite obtained from Isfahan, Iran. Differences can be attributed to various origins of zeolites ${ }^{24}$.

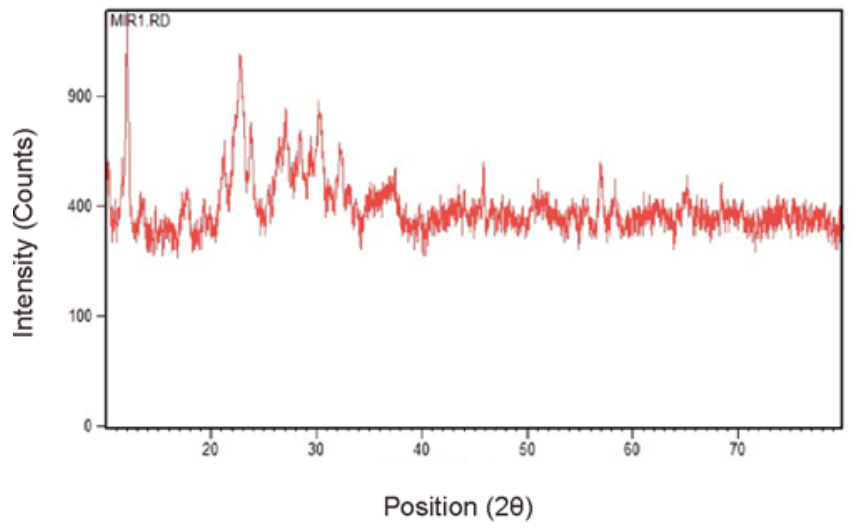

Figure 1. XRD patterns of natural clinoptilolite zeolite

The detailed view of the surface of zeolite taken by FE-SEM analysis is shown in Figure 2. The specific surface area of studied zeolite was $60.43 \mathrm{~m}^{2} / \mathrm{g}$ according to BET analysis which can be compared to value of $62.85 \mathrm{~m}^{2} / \mathrm{g}$ reported by in literature ${ }^{25}$ for a natural

Table 1. Research experimental procedure and the ranges of variables

\begin{tabular}{|c|c|c|c|c|c|c|}
\hline \multirow[t]{2}{*}{ Parameter } & \multicolumn{6}{|c|}{ Operational parameters } \\
\hline & $\begin{array}{c}\text { reaction } \\
\text { time }[\mathrm{min}]\end{array}$ & $\begin{array}{c}\text { adsorbent } \\
\text { dosage }[\mathrm{g} / \mathrm{L}]\end{array}$ & $\begin{array}{c}\text { mixing speed } \\
{[\mathrm{rpm}]}\end{array}$ & $\begin{array}{c}\text { temperature } \\
{\left[{ }^{\circ} \mathrm{C}\right]}\end{array}$ & initial $\mathrm{pH}$ & $\begin{array}{c}\mathrm{Cr}(\mathrm{VI}) \\
{[\mathrm{mg} / \mathrm{L}]}\end{array}$ \\
\hline Adsorbent dosage & 120 & $2-20$ & 250 & $20-25$ & 6 & 50 \\
\hline Reaction time & $5-150$ & 8 & 250 & $20-25$ & 2 & 50 \\
\hline Initial $\mathrm{Cr}(\mathrm{VI})$ & 30 & 8 & 250 & $20-25$ & 2 & $10-100$ \\
\hline Isotherm study & 30 & 8 & 250 & $20-25$ & 2 & $10-100$ \\
\hline
\end{tabular}


clinoptilolite from Romania and $50 \mathrm{~m}^{2} / \mathrm{g}$ for one from Isfahan, Iran ${ }^{24}$. The morphology of studied zeolite can be observed in Fe-SEM images (Fig. 2a) and based on elemental analysis through EDX (Fig. 2b), the zeolite was comprised mainly from $\mathrm{Si}$ and $\mathrm{O}$ followed by $\mathrm{Al}, \mathrm{K}$
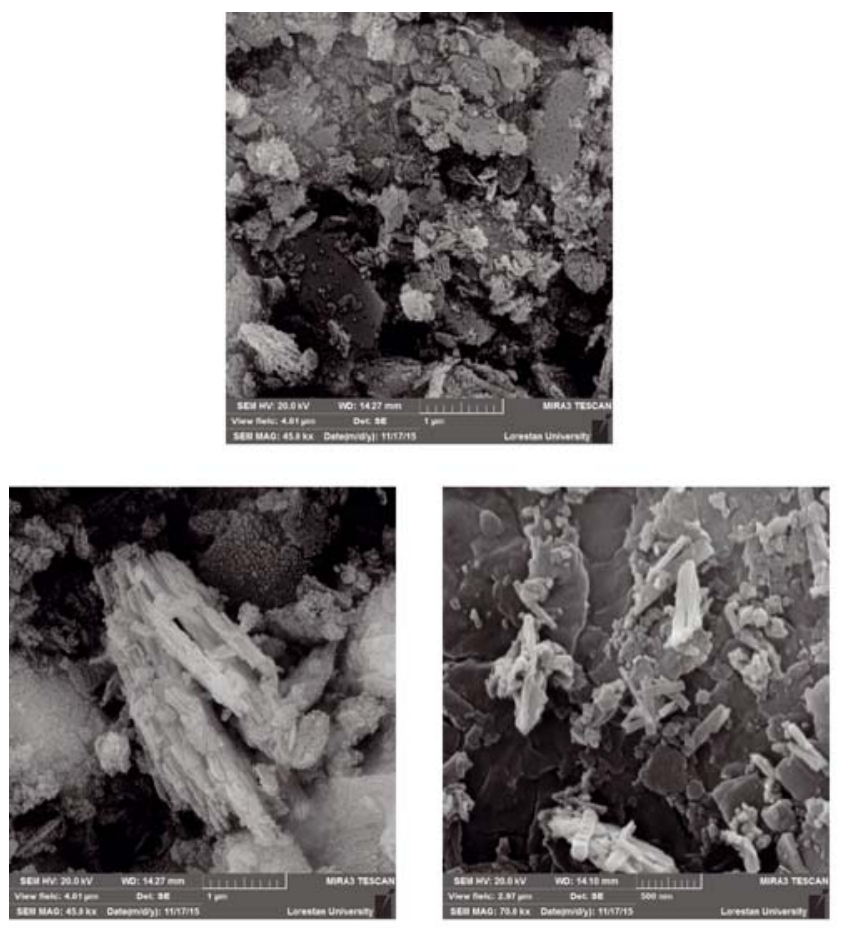

(A) the selective value for conducting the rest of experiments. Following the increase in adsorbent dosage, the specific surface area available for adsorption increases and improvement of removal efficiency is expected. It should be noted that the adsorption capacity decreased at the same time due to inter phase aggregation which

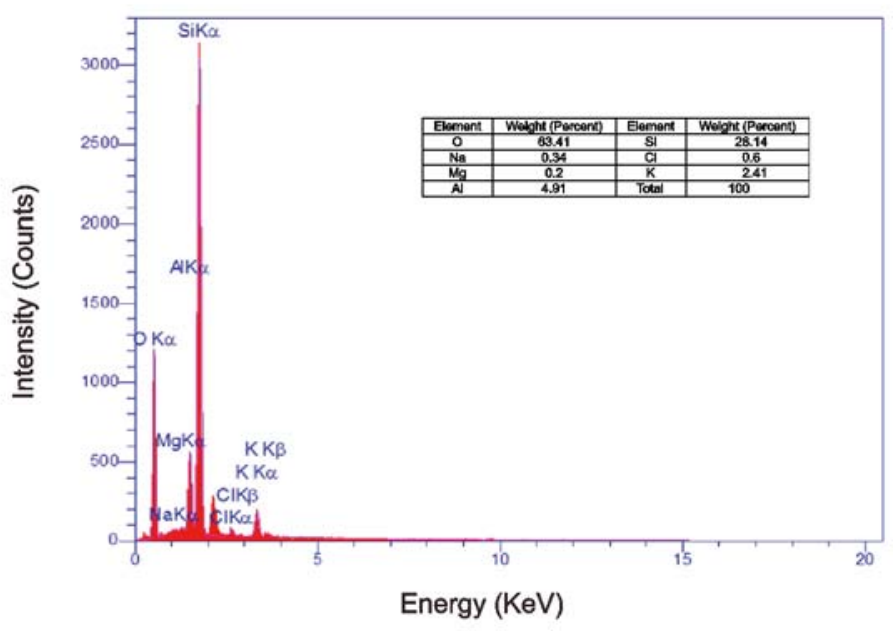

(B)

Figure 2. (a) FE-SEM images and (b) EDX spectrum of natural clinoptilolite zeolite

and $\mathrm{Na}$ which is similar to other studied natural zeolites in literature 2 , 27

\section{Effect of adsorbent dosage}

Along with increasing the adsorbent dosage from 2 to $8 \mathrm{~g} / \mathrm{L}$, a rapid increase in removal efficiency was observed and then gradually till $20 \mathrm{~g} / \mathrm{L}$ (Fig. 3). The most removal efficiency of $43.44 \%$ was observed for adsorbent dosage of $20 \mathrm{~g} / \mathrm{L}$. Also, the removal efficiency for adsorbent dosage of $8 \mathrm{~g} / \mathrm{L}$ was $42.99 \%$. Due to no significant difference in observed removal results for absorbent dosages of 8,10 and $20 \mathrm{~g} / \mathrm{L}(\mathrm{p}>0.05)$ and the advantage of using less amounts of material, the adsorbent dosage of $8 \mathrm{~g} / \mathrm{L}$ with the adsorption capacity $2.69 \mathrm{mg} / \mathrm{g}$ was selected as

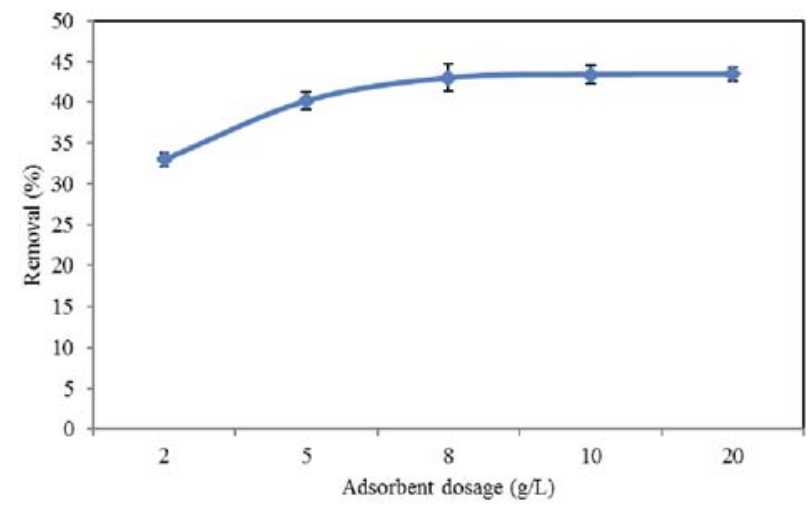

Figure 3. Effect of adsorbent dosage on $\mathrm{Cr}(\mathrm{VI})$ removal (initial $\mathrm{pH}$ : 6, $\mathrm{Cr}(\mathrm{VI})$ concentration: $50 \mathrm{mg} / \mathrm{L}$ and reaction time: $120 \mathrm{~min}$ ) results in decreases available adsorption sites and also increasing unsaturated sites ${ }^{\mathbf{2 8 - 3 0}}$ studied the humic acid removal with unmodified natural zeolite. Similar results were obtained in their study. Increasing the adsorbent dosages from 2 to $10 \mathrm{~g} / \mathrm{L}$, improved the removal efficiency from $30 \%$ to $80 \%$. They claimed that increasing the adsorbent dosage would lead to increase of Van Der Waals and electrostatic attraction forces between molecules of humic acid and natural zeolite.

\section{Effect of initial pH}

Low $\mathrm{pH}$ values favored the $\mathrm{Cr}(\mathrm{VI})$ removal efficiency. According to Figure 4 the removal efficiency decreased till the initial $\mathrm{pH}$ value of 6 and then increased gradually. The most removal efficiency of $48.98 \%$ with the adsorption capacity of $3.06 \mathrm{mg} / \mathrm{g}$ was obtained at $\mathrm{pH}$ value of 2 and the minimum of $43.6 \%$ at initial $\mathrm{pH}$ of 6 .

In the aqueous phase, $\mathrm{Cr}(\mathrm{VI})$ exists in different ionic forms $\left(\mathrm{HCrO}_{4}^{-}, \mathrm{Cr}_{2} \mathrm{O}_{7}{ }^{2-}, \mathrm{CrO}_{4}{ }^{2-}, \mathrm{HCr}_{2} \mathrm{O}_{7}\right.$. The total concentration of $\mathrm{Cr}(\mathrm{VI})$ and $\mathrm{pH}$ of the equilibrium solution are effective in distribution of $\mathrm{Cr}(\mathrm{VI})$ species in aqueous phase. The $\mathrm{CrO}_{4}{ }^{2-}$ anion prevails in basic or slightly acidic solution while the $\mathrm{Cr}_{2} \mathrm{O}_{7}^{2-}$ anion is dominant in acidic $\mathrm{Cr}(\mathrm{VI})$ aqueous solution ${ }^{31}$.

Low $\mathrm{pH}$ values lead to adsorption of oxyanions of $\mathrm{Cr}(\mathrm{VI})$ on the positively charged functional groups of zeolite. In addition, the $\mathrm{HCrO}_{4}^{-}$ions are most easily exchanged with $\mathrm{OH}^{-}$ions at active surfaces under acidic conditions. In high $\mathrm{pH}$ values, the interference by a high concentration of $\mathrm{OH}^{-}$ions may lead to lower 


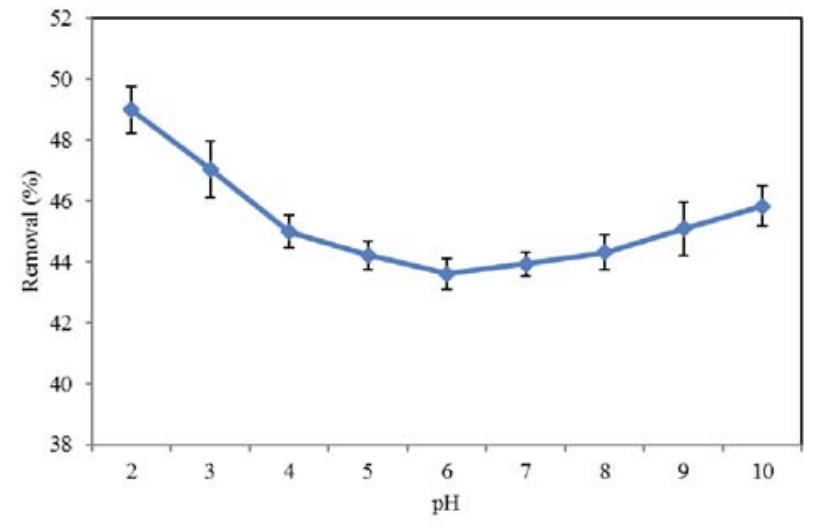

Figure 4. Effect of initial $\mathrm{pH}$ on $\mathrm{Cr}(\mathrm{VI})$ removal efficiency (adsorbent dosage: $8 \mathrm{~g} / \mathrm{L}$, initial $\mathrm{Cr}(\mathrm{VI})$ concentration: $50 \mathrm{mg} / \mathrm{L}$ and reaction time: $120 \mathrm{~min}$ )

removal efficiency. Increased amounts of $\mathrm{OH}^{-}$, increases the competition between $\mathrm{Cr}(\mathrm{VI})$ and $\mathrm{OH}^{-}$for occupying exchange sites in absorbent pore ${ }^{32,33}$.

\section{Effect of contact time}

The $\mathrm{Cr}(\mathrm{VI})$ removal efficiency improved along with the reaction time and reached to $49.18 \%$ at contact time of $150 \mathrm{~min}$ (Fig. 5). Considering the inflection at the reaction time of $30 \mathrm{~min}$ and observation the equilibrium time, the reaction time of 30 min with removal efficiency of $47.46 \%$ (adsorption capacity of $2.96 \mathrm{mg} / \mathrm{g}$ ) was determined as the optimum time. This optimum value was selected based on non-parametric Kruskal Wallis test, because of higher reaction times did not enhanced the removal significantly ( $\mathrm{p}$ value 0.668 ). Metal removal rates were higher in the early stages due to the higher number of vacancies on the adsorbent surface. Over the time, the number of adsorptive sites reduced due to the occupation by the metal ions, leading to the increased repulsive forces between the adsorbed $\mathrm{Cr}$ ions with the same charge. Therefore, the removal or the metal ion adsorption decreases ${ }^{\mathbf{3 4}, 35}$. Esfehani and Shamohammadi (2011) studied the manganese removal with natural and sodium zeolite. They observed that along with increasing the contact time to $25 \mathrm{~min}$, the absorption rate was high for both adsorbents. Thereafter, the adsorption rate decreased and reached to a constant value.

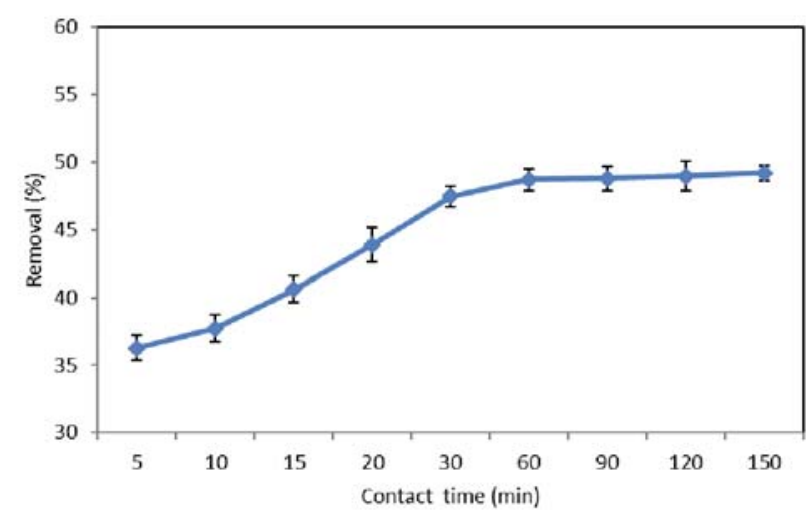

Figure 5. Effect of reaction time on $\mathrm{Cr}(\mathrm{VI})$ removal efficiency (adsorbent dosage: $8 \mathrm{~g} / \mathrm{L}, \mathrm{pH}: 2$ and initial $\mathrm{Cr}(\mathrm{VI})$ : $50 \mathrm{mg} / \mathrm{L})$

\section{Effect of the initial $\mathrm{Cr}$ (VI) concentration}

Along with the $\mathrm{Cr}(\mathrm{VI})$ concentration between 10-100 $\mathrm{mg} / \mathrm{L}$, removal efficiency varied from $98.53 \%$ to $44.94 \%$ respectively, but the amount of metal adsorbed per unit mass of adsorbent increased from 1.23 to $5.61 \mathrm{mg} / \mathrm{g}$ (Fig. 6). Removal efficiency has decreased along with increase in $\mathrm{Cr}(\mathrm{VI})$ concentration. According to Figure 6, enhancement of removal continues until the concentration of $50 \mathrm{mg} / \mathrm{L}$ and thereafter due to saturation of the active sites of the clinoptilolite zeolite for $\mathrm{Cr}(\mathrm{VI})$, no significant changes for the removing of $\mathrm{Cr}(\mathrm{VI})$ was observed $^{36}$. In a similar study performed by ${ }^{37}$ on the use of clinoptilolite zeolite for the removal of heavy metals,

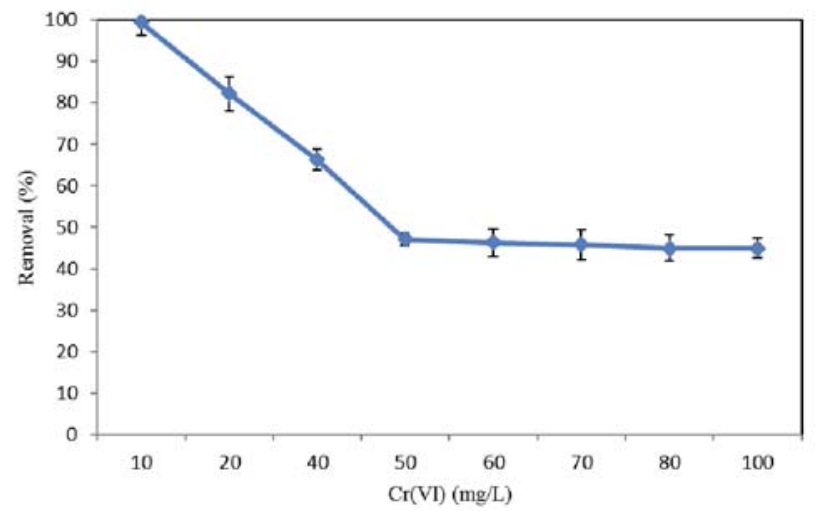

Figure 6. Effect of the initial $\mathrm{Cr}(\mathrm{VI})$ concentration $(\mathrm{pH}: 2$, reaction time: $30 \mathrm{~min}$ and adsorbent dosage: $8 \mathrm{~g} / \mathrm{L}$ )

the maximum adsorption capacities of 4.22, 27.7, 25.76 and $13.03 \mathrm{mg} / \mathrm{g}$ were obtained for cadmium, lead, copper and nickel, respectively.

\section{Adsorption isotherms}

Exact mathematical description of the equilibrium isotherm in satisfactory absorption process is necessary to design effective adsorption systems ${ }^{\mathbf{3 8}}$. In the current study, Freundlich, Langmuir, Temkin and Dubinin-Radushkevich isotherms were examined.

\section{Langmuir isotherm}

The Langmuir isotherm which assumes that adsorption sites on the surface of the adsorbent are uniform with same energy is given as Eq (3):

$q_{e}=q_{m} K C_{e} /\left(1+K C_{e}\right)$

Where, $\mathrm{q}_{\mathrm{e}}$ is the amount adsorbed at equilibrium $(\mathrm{mg} / \mathrm{g}), \mathrm{C}_{\mathrm{e}}$ is the equilibrium concentration $(\mathrm{mg} / \mathrm{L}), \mathrm{K}$ is the Langmuir constant for affinity of the binding sites $(\mathrm{L} / \mathrm{mg}), \mathrm{q}_{\mathrm{m}}$ is the maximum adsorption capacity $(\mathrm{mg} / \mathrm{g})$. The linear presentation of Langmuir equation is Eq. (4):

$q_{e}=q_{m} K C_{e} /\left(1+K C_{e}\right)$

The constant $\mathrm{q}_{\mathrm{m}}$ and $\mathrm{K}$ can be determined by plotting $\left(\mathrm{C}_{\mathrm{e}} / \mathrm{q}_{\mathrm{e}}\right)$ versus $\mathrm{C}_{\mathrm{e}}{ }^{39,25,40}$. Essential characteristic of Langmuir isotherm can be described in term of separation factor, $\mathrm{R}_{\mathrm{L}}$, as Eq. (5):

$R_{L}=1 /\left(1+C_{e} K\right)$

The $R_{L}$ values in the range of $0<R_{L}<1$ is favorable and $\mathrm{R}_{\mathrm{L}}>1$ would be unfavorable. According to obtained $R_{L}$ value range of $0.094-0.51$ for initial $\mathrm{Cr}(\mathrm{VI})$ concentrations of $10-100 \mathrm{mg} / \mathrm{L}$, the adsorption is favorable. 


\section{Freundlich isotherm}

The Freundlich isotherm describes sorption on a heterogeneous surface with exponential distribution of energy Eq. (6).

$q_{e}=K_{f} C_{e}^{\frac{1}{n}}$

The linear representation of Freundlich isotherm is as Eq. $(7)^{41}$ :

$\log q_{e}=\log K_{f}+1 / n \log C_{e}$

where $\mathrm{K}_{\mathrm{f}}(\mathrm{mg} / \mathrm{g})$ is Freundlich constant related to adsorption capacity, $\mathrm{n}$ is constant related to sorption intensity, $\mathrm{q}_{\mathrm{e}}(\mathrm{mg} / \mathrm{g})$ is the amount of adsorbed metal ions per unit weight of adsorbent and $\mathrm{C}_{\mathrm{e}}(\mathrm{mg} / \mathrm{L})$ is the concentration of free metal ions in solution ${ }^{19}$. The constants $K_{f}$ and $n$ were obtained from the slope and intercept of the plot of $\log \left(\mathrm{q}_{\mathrm{e}}\right)$ versus $\log \left(\mathrm{C}_{\mathrm{e}}\right)$. The values of $\mathrm{n}$ range between $1-10$ ( $n>1$ is favorable). According to $n$ constant of 2.99, the adsorption is favorable.

\section{Dubinin-Radushkevich (D-R) isotherm}

The Dubinin-Radushkevich (D-R) isotherm model is used to determine whether the adsorption process is physical or chemical and assumes heterogeneity of the surface energies. The linear form of D-R isotherm model is as Eq. (8):

$\ln q_{e}=\ln q_{m}-\beta \varepsilon^{2}$

Where $\mathrm{q}_{\mathrm{m}}(\mathrm{mol} / \mathrm{g})$ is the maximum sorption capacity, $\beta$ is a constant related to the mean sorption energy $\left(\mathrm{J}^{2} / \mathrm{mol}^{2}\right), \varepsilon$ is the Polanyi potential. The constants $\beta$ and $\mathrm{q}_{\mathrm{m}}$ can be obtained by plotting of $\ln \left(\mathrm{q}_{\mathrm{e}}\right)$ versus $\varepsilon^{2}$. Polanyi potential can be calculated through Eq. (9):

$\varepsilon=R T \ln \left(1+1 / C_{e}\right)$

Where $\mathrm{R}(8.314 \mathrm{~J} / \mathrm{mol} \mathrm{K})$ and $\mathrm{T}(\mathrm{K})$ are the gas constant and temperature, respectively. The sorption energy $\mathrm{E}_{\mathrm{s}}(\mathrm{kJ} / \mathrm{mol})$, which represents the transport free energy of solute the surface of adsorbent, can be calculated by Eq. (10):

$E_{s}=1 /\left(-2 \beta^{0.5}\right)$

For $\mathrm{E}_{\mathrm{s}}$ values between 8 and $16 \mathrm{~kJ} / \mathrm{mol}$, the adsorption process would be considered as a chemical, while $\mathrm{E}_{\mathrm{s}}<8$ $\mathrm{kJ} / \mathrm{mol}$, is a physical adsorption ${ }^{25,39,40}$. For the adsorption of $\mathrm{Cr}$ (VI) onto clinoptilolite zeolite, the value of $\mathrm{E}$ was calculated $12.7 \mathrm{~kJ} / \mathrm{mol}$, indicating the adsorption process occurs chemically.

\section{Temkin isotherm}

Assumes that the reduction in absorption heat is linear and adsorption is characterized by a uniform distribution of binding energy. The linear representation of Temkin isotherm is as Eq. (11):

$q_{e}=\left(q_{m} \ln K_{T}\right)+\left(q_{m} \ln C_{e}\right)$

Where, $\mathrm{q}_{\mathrm{e}}(\mathrm{mg} / \mathrm{g})$ is the amount of adsorbed metal ions per unit weight of adsorbent, $\mathrm{K}_{\mathrm{T}}$ is the Temkin constant $(\mathrm{L} / \mathrm{mol})^{39,42}$.

The results of the isotherm studies showed that the removal of $\mathrm{Cr}(\mathrm{VI})$ was consistent with Freundlich isotherm $\left(\mathrm{R}^{2}=0.951\right)$. The Freundlich isotherm indicates that the adsorbed molecules form a single layer on the surface of adsorbent particles with the same energy. Each molecule is adsorbed only in assigned one location. Therefore, probably a uniform distribution of active adsorbent surface sites is expected. The result for the Freundlich isotherm indicates the constant $\mathrm{n}$ of greater than 1 that confirms the adsorption of $\mathrm{Cr}(\mathrm{VI})$ onto zeolite ${ }^{39}$. But in term of adsorption capacity, experimental data $\left(\mathrm{q}_{\max }: 5.61 \mathrm{mg} / \mathrm{g}\right)$ were best followed Langmuir isotherm with $\mathrm{q}_{\max }$ value of $5.371 \mathrm{mg} / \mathrm{g}$. Also, according to E value of $9.128 \mathrm{Kj} /$ mole obtained from Dubinin-Radushkevich isotherm model, the absorption of $\mathrm{Cr}(\mathrm{VI})$ onto zeolite follows chemical mechanism $^{38}$. The maximum adsorption capacity in term $\mathrm{K}_{\mathrm{f}}$ constant for Freunlich isotherm of was 1.93 $\mathrm{mg} / \mathrm{g}$, compared to $10.42 \mathrm{mg} / \mathrm{g}$ for D-R isotherm, 5.376 $\mathrm{mg} / \mathrm{g}$ for Langmuir and 0.883 for Temkin isotherm. The results of the isotherms equations are shown in Table 2. The plot of freundlich adsorption isotherm is presented in Figure 7.The maximum adsorption capacity of $\mathrm{Cr}(\mathrm{VI})$ onto clinoptililite based on studied isotherm models are compared with findings of other researchers in Table 3.

Table 2. Isotherm parameters for $\mathrm{Cr}(\mathrm{VI})$ adsorption onto natural clinoptilolite zeolite

\begin{tabular}{|l|l|l|}
\hline \multicolumn{2}{|l|}{ Isotherm model } & Value \\
\hline \multirow{4}{*}{ Langmuir } & $\mathrm{q}_{\max }[\mathrm{mg} / \mathrm{g}]$ & 5.376 \\
\cline { 2 - 3 } & $\mathrm{K}[\mathrm{L} / \mathrm{mg}]$ & 0.096 \\
\cline { 2 - 3 } & $\mathrm{R}_{\mathrm{L}}$ & $0.094-0.51$ \\
\cline { 2 - 3 } & $\mathrm{R}^{2}$ & 0.919 \\
\hline \multirow{4}{*}{ Freundlich } & $\mathrm{K}_{\mathrm{F}}[\mathrm{mg} / \mathrm{g}]$ & 1.193 \\
\cline { 2 - 3 } & $\mathrm{n}$ & 2.99 \\
\cline { 2 - 3 } & $\mathrm{R}^{2}$ & 0.951 \\
\hline \multirow{5}{*}{ Dubinin-Radushkevich (D-R) } & $3.1 \times 10^{-3}$ \\
\cline { 2 - 3 } & $\mathrm{K}^{2}\left[\mathrm{~mol}^{2} / \mathrm{J}^{2}\right]$ & 10.42 \\
\cline { 2 - 3 } & $\mathrm{q}_{\mathrm{m}}[\mathrm{mol} / \mathrm{g}]$ & 12.7 \\
\cline { 2 - 3 } & $\left.\mathrm{E}^{2} \mathrm{~kJ} / \mathrm{mol}\right]$ & 0.948 \\
\cline { 2 - 3 } & $\mathrm{R}^{2}$ & 0.883 \\
\hline \multirow{5}{*}{ Temkin } & $\mathrm{q}_{\mathrm{m}}[\mathrm{mg} / \mathrm{g}]$ & 2.598 \\
\cline { 2 - 3 } & $\mathrm{K}_{\mathrm{T}}[\mathrm{L} / \mathrm{mg}]$ & 0.878 \\
\cline { 2 - 3 } & $\mathrm{R}^{2}$ & \\
\hline
\end{tabular}

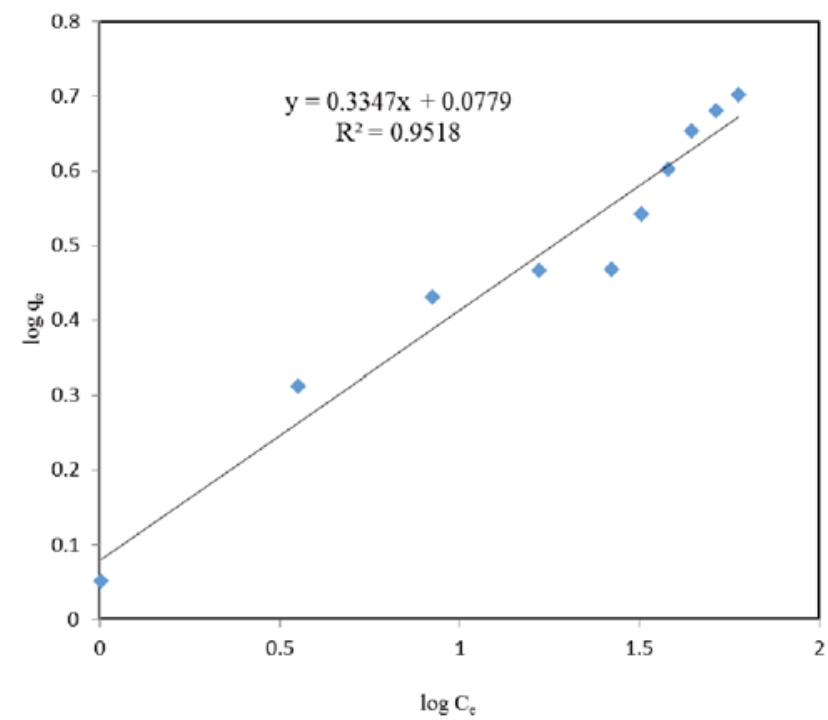

Figure 7. Freundlich, isotherm plot for $\mathrm{Cr}(\mathrm{VI})$ adsorption onto natural clinoptilolite $\mathrm{Cr}$ (VI) (concentration: 10-100 $\mathrm{mg} / \mathrm{L}$, contact time: $30 \mathrm{~min} \mathrm{pH}$ : 2 , adsorbent dosage: $8 \mathrm{~g} / \mathrm{L}$ and agitation speed: $150 \mathrm{rpm})$ ) 
Table 3. Maximum adsorption capacity of various adsorbents for $\mathrm{Cr}(\mathrm{VI})$ removal from aqueous solutions

\begin{tabular}{|l|c|c|}
\hline \multicolumn{1}{|c|}{ Adsorbent } & Maximum adsorption capacity [mg/g] & Reference \\
\hline Biosynthetic Schwertmannite & 38.82 & (Gan et al., 2015) \\
\hline Triethylenetetramine modified graphene oxide/chitosan composite & 219.5 & $(\mathrm{Ge}$ et al ., 2015) \\
\hline Aluminon-functionalized magnetic nanoparticles & 263.2 & (Yakout et al., 2015) \\
\hline Sulphate-crosslinked chitosan & 250.9 & (Shekhawat et al., 2015) \\
\hline Rice straw & 15.82 & (Wu et al., 2016) \\
\hline Australian zeolite & $5-11.2$ & (Nguyen et al., 2015) \\
\hline Natural zeolites modified with $N, N$-dimethyl dehydroabietylamine oxide & 69.94 & (Liu et al., 2014) \\
\hline Biomass material & 227.3 & (Zhong et al., 2013) \\
\hline Chitosan/polymethylmethacrylate composite & 92.5 & (Li et al., 2015) \\
\hline Current study (natural clinoptilolite) & 10.42 & - \\
\hline
\end{tabular}

\section{Adsorption kinetics}

In adsorption studies it is important to predict the adsorption rate which is useful in modeling of the adsorption process ${ }^{38}$. The kinetic study was carried out at an initial $\mathrm{Cr}(\mathrm{VI})$ concentration of $10 \mathrm{mg} / \mathrm{L}$, adsorbent dosage of $8 \mathrm{~g} / \mathrm{L}$, initial $\mathrm{pH}$ of 2 and a contact time of $30 \mathrm{~min}$. In the current study, Lagergren pseudo-first and pseudo-second order kinetic models were studied to determine the adsorption mechanism.

The linear equation of the pseudo- first order kinetic model is as Eq. (12)

$\log \left(q_{e}-q_{t}\right)=\log q_{e}-\left(k_{1, a d s} / 2.303\right) t$

Where $\mathrm{q}_{\mathrm{t}}(\mathrm{mg} / \mathrm{g})$ is the amount of adsorbed $\mathrm{Cr}(\mathrm{VI})$ at time $t$ and $k_{1 a d s}(1 / \mathrm{min})$ is the rate constant. By plotting $\log \left(\mathrm{q}_{\mathrm{e}}-\mathrm{q}_{\mathrm{t}}\right)$ versus time $\mathrm{q}_{\mathrm{e}}$ and $\mathrm{k}_{1}$ are obtained (Fig. 8a). The linear equation of the type 1 pseudo-second order kinetic model is as Eq. (13):

$\left(t / q_{t}\right)=1 / k_{2} q_{e}^{2}+\left(1 / q_{e}\right) t$

Where $\mathrm{k}_{2}(\mathrm{~g} / \mathrm{mg} \mathrm{min})$ is the rate constant of the equation ${ }^{43}$. By plotting $\mathrm{t} / \mathrm{q}_{\mathrm{t}}$ versus time, $\mathrm{q}_{\mathrm{e}}$ and $\mathrm{k}_{2}$ are obtained (Figure 8b).

Also, the linear equations of the type 2 pseudo-second order kinetic model is as Eq. (14):

$$
\left(1 / q_{t}\right)=1 / q_{t}+\left(1 / k_{2} q_{e}\right)(1 / t)
$$

By plotting $1 / \mathrm{q}_{\mathrm{t}}$ versus time $1 / \mathrm{t}, \mathrm{q}_{\mathrm{e}}$ and $\mathrm{k}_{2}$ are obtained (Fig. 8c).

The linear equations of the type 3 pseudo-second order kinetic model is as Eq. $(15)^{44}$ :

$(1 / t)=\left(k_{2}-q_{e 2} / q_{t}\right)-\left(k_{2}-q_{e 2} / q_{e}\right)$

By plotting $1 / \mathrm{t}$ versus time $1 / \mathrm{t}, \mathrm{q}_{\mathrm{e}}$ and $\mathrm{k}_{2}$ are obtained (Fig. 8d).
Reaction time and dimensions of the reactor depend on the adsorption kinetics ${ }^{45}$. The kinetic parameters and correlation coefficients of pseudo-first order and pseudo-second order kinetic models are presented in Table 4. In the current study, experimental data were best fitted to type 1 pseudo-second order model for $\mathrm{Cr}(\mathrm{VI})$ adsorption onto natural clinoptilolite zeolite $\left(\mathrm{R}^{2}=1\right.$ and also the affinity of calculated $q_{e}$ to the experimental $q_{e}$ ). It is believed that adsorption involves mechanisms such as chemical and electrostatic interactions between adsorption sites and metal ion being adsorbed. Consequently, pseudo-second order model provides the best correlation for chemical adsorption. In the case of metal adsorption via diffusion through a boundary layer, the kinetic of process should follow the pseudo-first order model ${ }^{34}$.

\section{Desorption}

In order to predict reusability of clinoptilolite natural zeolite, four adsorption-desorption cycles were considered. The $\mathrm{Cr}(\mathrm{VI})$ initial concentration of $50 \mathrm{mg} / \mathrm{L}$ was studied. Desorption ratio (DR \%) was determined through Eq. $(16)^{46,47}$ :

$D R \%=\frac{\text { Amount of desorbed metal ion }}{\text { Amount of adsorbed metal ion }} \times 100$

It was observed that $74.31 \%$ of the adsorbed $\mathrm{Cr}(\mathrm{VI})$ was desorbed in the first adsorption-desorption cycle, and decreased to $41.69 \%$ in the fourth cycle. The total reduction after four cycles was $32.62 \%$, demonstrating the acceptable reusability of used clinoptilolite zeolite for full-scale applications considering its low cost and ease of access.

Table 4. Kinetic parameters of $\mathrm{Cr}(\mathrm{VI})$ adsorption

\begin{tabular}{|c|c|c|c|c|}
\hline Kinetic models & & Coefficient & Value & $\mathrm{q}_{\mathrm{exp}}[\mathrm{mg} / \mathrm{g}]$ \\
\hline \multirow{3}{*}{\multicolumn{2}{|c|}{ Pseudo-first order }} & $\mathrm{K}_{1}[\mathrm{~L} / \mathrm{g}]$ & 0.099 & \multirow{3}{*}{1.25} \\
\hline & & $q_{\text {e cal. }}[\mathrm{mg} / \mathrm{g}]$ & 0.155 & \\
\hline & & $\mathrm{R}_{2}$ & 0.943 & \\
\hline \multirow{9}{*}{ Pseudo-second order } & \multirow[t]{3}{*}{ Type(I) } & $\mathrm{K}_{2}[\mathrm{~g} / \mathrm{mg} \cdot \mathrm{min}]$ & 1.39 & \multirow{9}{*}{1.25} \\
\hline & & $\mathrm{q}_{\mathrm{e} \mathrm{cal}}[\mathrm{mg} / \mathrm{g}]$ & 1.26 & \\
\hline & & $\mathrm{R}_{2}$ & 1 & \\
\hline & \multirow[t]{3}{*}{ Type(II) } & $\mathrm{K}_{2}[\mathrm{~g} / \mathrm{mg} \cdot \mathrm{min}]$ & 1.37 & \\
\hline & & $\mathrm{q}_{\mathrm{ecal}}[\mathrm{mg} / \mathrm{g}]$ & -0.57 & \\
\hline & & $\mathrm{R}_{2}$ & 0.979 & \\
\hline & \multirow[t]{3}{*}{ Type(III) } & $\mathrm{K}_{2}$ [g/mg $\left.\mathrm{min}\right]$ & 1.362 & \\
\hline & & $q_{\text {e cal }}[\mathrm{mg} / \mathrm{g}]$ & 1.26 & \\
\hline & & $\mathrm{R}_{2}$ & 0.982 & \\
\hline
\end{tabular}



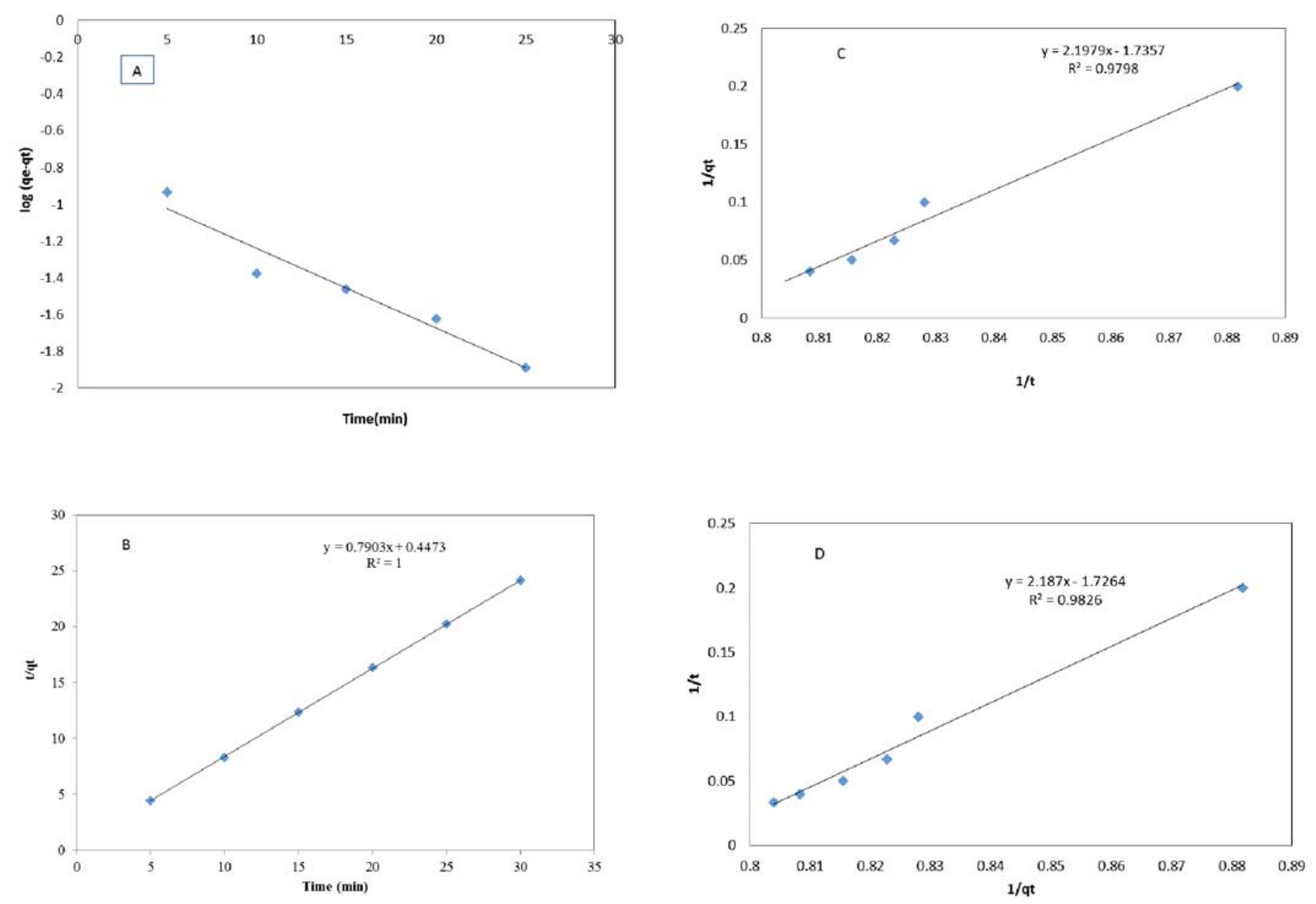

Figure 8. The fitting of different kinetic models for $\mathrm{Cr}(\mathrm{VI})$ adsorption on clinoptilolite zeolite with concentration of $10 \mathrm{mg} / \mathrm{L}$ : (a) pseudo-first order; (b), (c), (d) type 1-3 pseudo-second order, respectively

\section{CONCLUSION}

In the current study, capability of a natural clinoptilolite zeolite was studied for $\mathrm{Cr}(\mathrm{VI})$ dsorption in aqueous solution. Results indicated acceptable capability of studied zeolite for removal of $\mathrm{Cr}(\mathrm{VI})$ under determined condition. Freundlich isotherm model was best fitted with experimental data, indicating that the adsorption of $\mathrm{Cr}(\mathrm{VI})$ onto the clinoptilolite zeolite was multilayer adsorption. Negative charges of $\mathrm{Cr}(\mathrm{VI})$ along with positive charges of zeolite surface in initial $\mathrm{pH}$ value of 2 , led to a chemical binding in adsorption process. The chemical adsorption of $\mathrm{Cr}(\mathrm{VI})$ was confirmed by Calculated $\mathrm{E}$ value of $9.128 \mathrm{Kj} / \mathrm{mole}$ for $\mathrm{D}-\mathrm{R}$ isotherm. The kinetic data closely follow the type I pseudo-second order kinetic model. Since natural Clinoptilolite zeolite is a low-cost and naturally available adsorbent and based on findings of current study, it can be considered as an efficient, viable and reliable adsorbent for removal of $\mathrm{Cr}(\mathrm{VI})$ from aqueous solutions.

\section{CONFLICT OF INTREST}

The authors declare that they have no conflict interest.

\section{ACKNOWLEDGMENT}

This paper is issued from thesis of Mohammad Javad Ahmadi and financial support was provided by Ahvaz Jundishapur University of Medical Sciences (Grant no: ETRC 9323).

\section{LITERATURE CITED}

1. Gueye, M.Y.R., Kafack, F.T. \& Blin, J. (2014). High efficiency activated carbons from African biomass residues for the removal of chromium(VI) from wastewater. J. Environ. Chem. Eng. 2(1), 273-281. DOI : 10.1016/j.jece.2013.12.014.

2. Sreenivas, K.M., Gokhale, M.B.I. \& Lele, S.S. (2014). Reutilization of ash gourd (Benincasa hispida) peel waste for chromium (VI) biosorption: Equilibrium and column studies. J. Environ. Chem. Eng. 2(1), 455-462. DOI: 10.1016/j. jece.2014.01.017.

3. Nosuhi, M. \& Nezamzadeh-Ejhieh, A. (2017). High catalytic activity of $\mathrm{Fe}(\mathrm{II})$-clinoptilolite nanoparticales for indirect voltammetric determination of dichromate: Experimental design by response surface methodology (RSM). J. Electro. Acta, 223, 47-62. DOI: 10.1016/j.electacta.2016.12.011.

4. Darvishi Cheshmeh Soltani, R.J., Safari, S. \& Rajaei, M.M.S. (2016). Enhanced sonocatalysis of textile wastewater using bentonite-supported $\mathrm{ZnO}$ nanoparticles: Response surface methodological approach. J. Environ. Manage 179, 47-57. DOI: 10.1016/j.jenvman.2016.05.001.

5. Ahluwalia, S.S. \& Goyal, D. (2007). Microbial and plant derived biomass for removal of heavy metals from wastewater. J. Bioresour. Technol. 98(12), 2243-2257. DOI: 10.1016/j. biortech.2005.12.006.

6. Jorfi, S., Ahmadi, M., Khataeed, A. \& Safarie, M. (2017). Sono-assisted adsorption of a textile dye on milk vetch-derived charcoal supported by silica nanopowder. J. Environ. Manage. 187, 111-121. DOI: 10.1016/j.jenvman.2016.11.042.

7. Soltani, R.D.J.S., Ramezani, H. \& Purfadakari, S. (2016). Ultrasonically induced $\mathrm{ZnO}$-biosilica nanocomposite for degradation of a textile dye in aqueous phase. J. Ultra. Sono. Chem. 28, 69-78. DOI: 10.1016/j.ultsonch.2015.07.002. 
8. Ahmadi, M., Jaafarzadeh, N., Mostoufid, A., Saeedie, R., Barzegarc, G. \& Jorfia, S. (2017). Enhanced photocatalytic degradation of tetracycline and real pharmaceutical wastewater using MWCNT/TiO 2 nano-composite. J. Environ. Manage 186, 55-63. DOI: 10.1016/j.jenvman.2016.09.088.

9. Rajic, N., Jovanovic, S.M., Logar, N.Z., Mazaj, M. \& Kaucic, V. (2010). Removal of nickel(II) ions from aqueous solutions using the natural clinoptilolite and preparation of nano-NiO on the exhausted clinoptilolite. J. Appl. Surf. Sci. 257(5), 1524-1532. DOI: 10.1016/j.apsusc.2010.08.090.

10. Bagheri Ghomi, A. \& Ashayeri, V. (2012). Photocatalytic efficiency of $\mathrm{CuFe} 2 \mathrm{O} 4$ by supporting on clinoptilolite in the decolorization of acid red 206 aqueous solutions. Iranian J. Cataly. 2(3), 135-140.

11. Jha, V.K. \& Hayashi, S.H. (2009). Modification on natural clinoptilolite zeolite for its NH4+ retention capacity. J. Hazard. Mater. 169(1-3), 29-35. DOI: 10.1016/j.jhazmat.2009.03.052.

12. Gedik, K. \& Imamoglu, I. (2008). Removal of cadmium from aqueous solutions using clinoptilolite: influence of pretreatment and regeneration. J. Hazard. Mater. 155(1-2), 385-392. DOI: 10.1016/j.jhazmat.2007.12.101.

13. Kocaoba, S., Orhan, Y. \& Akyüz, T. (2007). Kinetics and equilibrium studies of heavy metal ions removalby use of natural zeolite. J. Desali. 214(1-3), 1-10. DOI: 10.1016/j. desal.2006.09.023.

14. Vassileva, P. \& Voikova, D. (2009). Investigation on natural and pretreated Bulgarian clinoptilolite for ammonium ions removal from aqueous solutions. J. Hazard. Mater. 170 (2-3), 948-953. DOI: 10.1016/j.jhazmat.2009.05.062.

15. Danesh-Khorasgani, M. \& Nezamzadeh-Ejhieh, A. (2016). PVC-zeolite nanoparticle-surfactant anion exchanger membrane: preparation, characterization, and its application in development of ion-selective electrode for detection of sulfate. J. Solid State. Electro. Chem. 20(10), 2827-2833. DOI: 10.1007/ s10008-016-3265-9.

16. Hashemi, S. \& Nezamzadeh-Ejhieh, A. (2014). A novel chromium selective electrode based on surfactant-modified Iranian clinoptilolite nanoparticles. J. Desali \& Water Treat. 57, 3304-3314. DOI: 10.1080/19443994.2014.989916.

17. Sharafzadeh, S. \& Nezamzadeh-Ejhieh, A. (2015). Using of anionic adsorption property of a surfactant modified clinoptilolite nano-particles in modification of carbon paste electrode as effective ingredient for determination of anionic ascorbic acid species in presence of cationic dopamine species. J. Electrochim. Acta 184, 371-380. DOI: 10.1016/j.electacta.2015.09.164.

18. Deravanesiyan, M. \& Malekpour, M.B.A. (2015). The removal of $\mathrm{Cr}$ (III) and Co (II) ions from aqueous solution by two mechanisms using a new sorbent (alumina nanoparticles immobilized zeolite) - Equilibrium, kinetic and thermodynamic studies. J. Mol. Liq. 209, 246-257. DOI: 10.1016/j. molliq.2015.05.038.

19. Ouadjenia-Marouf, R., Schott, J. \& Yahiaoui, A. (2013). Removal of $\mathrm{Cu}(\mathrm{II}), \mathrm{Cd}(\mathrm{II})$ and $\mathrm{Cr}(\mathrm{III})$ ions from aqueous solution by dam silt. J. Arab. Chem. 6(4), 401-406. DOI: 10.1016/j. arabjc.2010.10.018.

20. Ajoudanian, N. \& Nezamzadeh-Ejhieh, A. (2015). Enhanced photocatalytic activity of nickel oxide supported on clinoptilolite nanoparticles for the photodegradation of aqueous cephalexin. J. Mater. Sci. Semi Proce. 36, 162-169. DOI: 10.1016/j.mssp.2015.03.042.

21. Dianati Tilaki, R.A., Kahe, D. \& Zazouli, M.A. (2013). Efficiency of Zeolite Clinoptilolite in Removal of Ammoniumion from Polluted Waters. J. Maz. Univ. Med. Sci. 22(97), 250-256. http://jmums.mazums.ac.ir/article-1-1815-en.html.

22. APHA, 2005. Standard Methods for the Examination of Water \& Wastewater. Washington DC.

23. Jiménez-cedillo, M.J., Olguín, M.T. \& Fall, Ch. (2009). Adsorption kinetic of arsenates as water pollutant on iron , manganese and iron - manganese-modified clinoptilolite-rich tuffs. J. Hazard. Mater. 163(2-3), 939-945. DOI: 10.1016/j. jhazmat.2008.07.049.

24. Derikvandi, H. \& Nezamzadeh-Ejhieh, A. (2017). A comprehensive study on electrochemical and photocatalytic activity of SnO2-ZnO/clinoptilolite nanoparticles. J. Molecu. Catal. A: Chem. 426, 158-169. DOI: 10.1016/j.molcata.2016.11.011.

25. Mihaly-Cozmuta, L., Mihaly-Cozmuta, A., Peter, A., Nicula, C., Tutu, H. \& Silipas, D. (2014). Adsorption of heavy metal cations by Na-clinoptilolite: Equilibrium and selectivity studies. J. Environ. Manage 137, 69-80. DOI: 10.1016/j. jenvman.2014.02.007.

26. Hernández-Montoya, V., Pérez-Cruz, M.A., Mendoza-Castillo, D.I., Moreno-Virgen, M.R. \& Bonilla-Petriciolet, A. (2013). Competitive adsorption of dyes and heavy metals on zeolitic structures. J. Environ. Manage 116, 213-221. DOI: 10.1016/j.jenvman.2012.12.010.

27. Wang, S. \& Ariyanto, E. (2007). Competitive adsorption of malachite green and $\mathrm{Pb}$ ions on natural zeolite. J. Coll. Interf. Sci. 314(1), 25-31. DOI: 10.1016/j.jcis.2007.05.032.

28. Moussavi, G., Talebi, S., Farrokhi, M. \& Sabouti, R.M. (2011). The investigation of mechanism, kinetic and isotherm of ammonia and humic acid co-adsorption onto natural zeolite. $J$. Chem. Eng. 171(3), 1159-1169. DOI: 10.1016/j.cej.2011.05.016.

29. Inglezakis, V.J., Stylianou, M., Gkantzou, D. \& Loizidou, M.D. (2007). Removal of $\mathrm{Pb}(\mathrm{II})$ from aqueous solutions by using clinoptilolite and bentonite as adsorbents. J. Desali. 210(1-3), 248-256. DOI: 10.1016/j.desal.2006.05.049.

30. Dal Bosco, S.M., Jimenez, R.S. \& Carvalho, W.A. (2005). Removal of toxic metals from wastewater by Brazilian natural scolecite. J. Coll. Interf. Sci. 281(2) 424-431. DOI: 10.1016/j. jcis.2004.08.060.

31. Nezamzadeh-Ejhieh, A. \& Raja, G. (2013). Modification of Nanoclinoptilolite Zeolite with Hexadecyltrimethylammonium Surfactant as an Active Ingredient of Chromate-Selective Membrane Electrode. J. Chemis. 1-13. DOI: 10.1155/2013/685290.

32. Hegazi, H.A. (2013). Removal of heavy metals from wastewater using agricultural and industrial wastes as adsorbents. J. HBRC 9(3), 276-282. DOI: 10.1016/j.hbrcj.2013.08.004.

33. Sar1, A. \& Tuzen, M. (2008). Biosorption of total chromium from aqueous solution by red algae (Ceramium virgatum): Equilibrium, kinetic and thermodynamic studies. J. Hazard. Mater. 160(2-3), 349-355. DOI: 10.1016/j.jhazmat.2008.03.005.

34. Darvishi-Cheshme Soltani, R., Shams-Khorramabadi, G., Khataee, A.R. \& Jorfi, S. (2013).Silica nanopowders/alginate composite for adsorption of lead (II) ions in aqueous solutions. J. Taiwan Inst. Chem. Eng. 45(3), 973-980. DOI: 10.1016/j. jtice.2013.09.014.

35. Esfehani, A. \& Shamohammadi-Heidari, Z. (2011). Manganese Removal from Aqueous Solution by Natural and Sodium Modified Zeolite. J. Environ. Stud. 37, 28-30.

36. Borandegi, M. \& Nezamzadeh-Ejhieh, A. (2015). Enhanced removal efficiency of clinoptilolite nano-particles toward Co(II) from aqueous solution by modification with glutamic acid. J. Coll. \&Surf. A: Physicochem \& Engin Aspects. 479, 35-45. DOI: 10.1016/j.colsurfa.2015.03.040.

37. Sprynskyy, M., Buszewski, B., Terzyk, A.P. \& Namieśnik, J. (2006). Study of the selection mechanism of heavy metal $(\mathrm{Pb} 2+, \mathrm{Cu} 2+, \mathrm{Ni} 2+$, and $\mathrm{Cd} 2+)$ adsorption on clinoptilolite. J. Coll. Inter. Sci. 304(1), 21-28. DOI: 10.1016/j.jcis.2006.07.068.

38. Malamis, S. \& Katsou, F. (2013). A review on zinc and nickel adsorption on natural and modified zeolite, bentonite and vermiculite: Examination of process parameters, kinetics and isotherms. J. Hazard. Mater. 252-253, 428-461. DOI: 10.1016/j.jhazmat.2013.03.024.

39. Behnamfard, A. \& Salarirad, M.M. (2009). Equilibrium and kinetic studies on free cyanide adsorption from aqueous solution by activated carbon. J. Hazard. Mater. 170(1), 127-133. DOI: 10.1016/j.jhazmat.2009.04.124.

40. Anari-Anaraki, M. \& Nezamzadeh-Ejhieh, A. (2015). Modification of an Iranian clinoptilolite nano-particles by he- 
xadecyltrimethyl ammonium cationic surfactant and dithizone for removal of $\mathrm{Pb}$ (II) from aqueous solution. J. Coll. .Interf. Sci. 440, 272-281. DOI: 10.1016/j.jcis.2014.11.017.

41. Naghash, A. \& Nezamzadeh-Ejhieh, A. (2015). Comparison of the efficiency of modified clinoptilolite with HDTMA and HDP surfactants for the removal of phosphate in aqueous solutions. J. Industri \& Eng. Chem. 31, 185-191. DOI: 10.1016/j. jiec.2015.06.022.

42. Dizge, N., Keskinler, B. \& Barlas, H. (2009). Sorption of Ni ( II ) ions from aqueous solution by Lewatit cation-exchange resin. J. Hazard. Mater. 167(1-3), 915-926. DOI: 10.1016/j.jhazmat.2009.01.073.

43. Najafi, M., Yousefi, Y. \& Rafati, A.A. (2012). Synthesis, characterization and adsorption studies of several heavy metal ions on amino-functionalized silica nano hollow sphere and silica gel. J. Sep. Purif. Technol. 85, 193-205. DOI: 10.1016/j. seppur.2011.10.011.

44. Heidari-Chaleshtori, M. \& Nezamzadeh-Ejhieh, A. (2015). Clinoptilolite nano-particles modified with aspartic acid for removal of $\mathrm{Cu}(\mathrm{II})$ from aqueous solutions: isotherms and kinetic aspects. J. New. Chem. 39, 9396-9406. DOI: 10.1039/ C5NJ01631B.

45. Guo, H., Zhang, S., Kou, Z., Zhai, S., Ma,W. \& Yang, Y. (2015). Removal of cadmium(II) from aqueous solutions by chemically modified maize straw. J. Carbohydr. Polym. 115, 177-85. DOI: 10.1016/j.carbpol.2014.08.041.

46. Ozay, O., Ekici, S., Baran, Y., Aktas, N. \& Sahiner, N. (2009). Removal of toxic metal ions with magnetic hydrogels. J. Water Res. 43. 4403-4411. DOI: 10.1016/j.watres.2009.06.058.

47. Rezaee, A., Godini, H. \& Jorfi, S. (2010). Nitrate removal from aqueous solution using mgcl2 impregnated activated carbon. J. Environ. Eng. \& Manag. 9(3), 449-452. 